\title{
Communication management during the veld fires of 23 August 2011 in the Tlokwe Local Municipality: A cautionary tale
}

\begin{tabular}{|c|c|}
\hline \multicolumn{2}{|c|}{$\begin{array}{l}\text { Author: } \\
\text { Magrita N. Wiggill }{ }^{1}\end{array}$} \\
\hline \multicolumn{2}{|c|}{$\begin{array}{l}\text { Affiliation: } \\
{ }^{1} \text { School of Communication }\end{array}$} \\
\hline \multicolumn{2}{|c|}{$\begin{array}{l}\text { Correspondence to: } \\
\text { Magrita Wiggill }\end{array}$} \\
\hline \multicolumn{2}{|c|}{$\begin{array}{l}\text { Email: } \\
\text { marlene.wiggill@nwu.ac.za }\end{array}$} \\
\hline \multicolumn{2}{|c|}{$\begin{array}{l}\text { Postal address: } \\
\text { PO Bag X6001, } \\
\text { Potchefstroom 2520, } \\
\text { South Africa }\end{array}$} \\
\hline \multicolumn{2}{|c|}{$\begin{array}{l}\text { Received: } 19 \text { Aug. } 2012 \\
\text { Accepted: } 17 \text { Jan. } 2013 \\
\text { Published: } 05 \text { Apr. } 2013\end{array}$} \\
\hline \multicolumn{2}{|c|}{$\begin{array}{l}\text { Keywords: } \\
\text { communication } \\
\text { management; relationship } \\
\text { management; veld fires; } \\
\text { disasters; emergency services }\end{array}$} \\
\hline \multicolumn{2}{|c|}{$\begin{array}{l}\text { How to cite this article: } \\
\text { Wiggill, M.N., 2013, } \\
\text { 'Communication } \\
\text { management during the veld } \\
\text { fires of } 23 \text { August } 2011 \text { in the } \\
\text { Tlokwe Local Municipality: } \\
\text { A cautionary tale', Jàmbá: } \\
\text { Journal of Disaster Risk } \\
\text { Studies 5(2), Art. \#85, } \\
9 \text { pages. http://dx.doi. } \\
\text { org/10.4102/jamba.v5i2.85 }\end{array}$} \\
\hline \multicolumn{2}{|c|}{$\begin{array}{l}\text { 1st Biennial Conference, } \\
\text { Southern African Society for } \\
\text { Disaster Reduction (SASDiR), } \\
09 \text { to } 11 \text { October 2012, } \\
\text { Potchefstroom, South Africa. }\end{array}$} \\
\hline \multicolumn{2}{|c|}{$\begin{array}{l}\text { C 2013. The Authors } \\
\text { Licensee: AOSIS } \\
\text { OpenJournals. This w } \\
\text { is licensed under the } \\
\text { Creative Commons } \\
\text { Attribution License. }\end{array}$} \\
\hline \multicolumn{2}{|l|}{ Read online: } \\
\hline 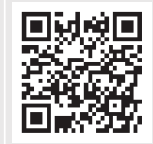 & $\begin{array}{l}\text { Scan this QR } \\
\text { code with your } \\
\text { smart phone or } \\
\text { mobile device } \\
\text { to read online. }\end{array}$ \\
\hline
\end{tabular}

Background: A veld fire disaster in the Tlokwe Local Municipality on 23 August 2011, resulted in an estimated monetary loss of over R43 million. The veld fire disaster was characterised by a lack of strategic management and a subsequent lack of planned, coordinated communication between all role players involved. The lack of strategic communication management indirectly contributed to the losses suffered during the disaster, and afterwards relationships between many role players were strained.

Objectives and method: The objectives for the qualitative research project were to determine the different role players' perception of communication management during the veld fires of 23 August 2011, and in what way relationships between role players were affected by the lack of communication management during the veld fire disaster. Data were gathered by means of semi-structured interviews with the relevant role players.

Results and conclusion: Most of the role players were convinced that communication was not managed effectively on 23 August 2011. It resulted in, most especially, a loss of trust and perceived lack of commitment between some of the role players. It is recommended that emergency services and other role players receive more training (also focusing on communication management), participate in simulations and incorporate a communication and relationship management approach to disaster risk management.

\section{Introduction and background to the study}

On 23 August 2011, the rural areas of the Tlokwe Local Municipality in the North-West province experienced a devastating veld fire, causing losses in farming infrastructure, grazing and livestock mounting to an estimated monetary loss of approximately R43 million (Van Niekerk \& Coetzee 2011). Two people lost their lives in the fires, and six were injured (Cilliers 2011; Coleman 2011). A local state of disaster was subsequently declared in the Tlokwe Local Municipality.

The Fire Danger Index (FDI) (section 9[4][c] and 9[4][d] of the National Veld and Forest Fire Act 101 of 1998) (South Africa 1998) indicated 23 August 2011 as a 'code red day', which means that extreme and disastrous veld fires were a strong possibility. During that day, wind speeds of between $73 \mathrm{~km} / \mathrm{h}$ and $100 \mathrm{~km} / \mathrm{h}$ were recorded by the South African Weather Service. According to the Rapid Impact Assessment Report (Van Niekerk \& Coetzee 2011), the veld fires of 23 August 2011 were 'the most intense and devastating veld fire[s] in the recorded history of the local municipality'. The veld fires started north of Potchefstroom at approximately 12:00 pm, but another fire was reported south of Potchefstroom at approximately 14:26. Soon, 13 veld fires raged throughout the Tlokwe Local Municipality, exhausting all available fire-fighting resources. The cause of the veld fires were mostly ascribed to Eskom power lines touching each other due to the strong wind and subsequently creating short-circuits that set the veld on fire (Davies 2011; Van Niekerk \& Coetzee 2011).

An estimation of the veld fire damages between 23 August and 12 September 2011 showed that 292965 hectares of natural grazing and 6765 hectares of planted pastures were destroyed (Davies 2011). The total number of livestock and game burned to death totaled 3666, including cattle, sheep, ostriches and horses (Davies 2011). To illustrate the overwhelming nature of the veld fires, the interviewed farmers said that 'everybody did their best to extinguish the veld fires, but the wind was very strong'. One farmer reported that he drove at ' $70 \mathrm{~km} / \mathrm{h}$ along a gravel road to escape the fire, but the fire ran next to us. It [the wind] was just too strong.' This farmer lost more than 600 cattle in the fire, of which nearly 200 had to be put down due to severe burn wounds. This farmer's estimated monetary loss was more than R6 million (Davies 2011). Another farmer said that a neighbour 'had 2000 hectares [of land] and it took 10 minutes [to burn down]'. 
Veld fires during winter in the Tlokwe Local Municipality are a known hazard (Anon 2008, 2010; Cilliers 2011; Davies 2011; Meyer 2002; Tau 2008; Van der Walt 2012) that can quickly turn into a disaster, as happened on 23 August 2011. Since they are a known hazard, all role players should have a plan and/or procedure for managing a veld fire in order to prevent it from becoming a disaster, and this should include having a disaster communication strategy and plan. However, the veld fires of 23 August 2011 were characterised by a lack of strategically planned and coordinated communication between all role players involved. The lack of communication led to a situation in which information was not conveyed to all the role players; there was uncertainty about the chain of command; and not all farmers got help in time. Since strong relationships are the most important outcome of communication management, it can be deduced that the lack of communication management badly damaged relationships between all role players during the fires. Strategic communication and relationship management as the theoretical focus of the study will be discussed next.

\section{Key focus of the study Strategic communication management}

Strategic communication is a management function that establishes and maintains mutually beneficial relationships between an organisation and its strategic stakeholders, because relationships assist the organisation in managing its interdependence with the environment (Cutlip, Center \& Broom 2000; Grunig, Grunig \& Dozier 2002; Jahansoozi 2007; Ledingham \& Bruning 1998; Steyn 2007). Communication practitioners manage strategically when they are able to identify and segment strategic stakeholders, and balance the mission and needs of the organisation with what the different stakeholders, or the environment, will allow or encourage it to do (Grunig \& Grunig 2000; Newsom, Turk \& Kruckeberg 2010). The most strategic role of a communication practitioner is to scan and monitor the stakeholder and the societal environment, interpret this strategic information, assess its implications for the organisation, and incorporate it into the organisational strategy formulation process (Steyn 2007; Newsom et al. 2010). Environmental scanning is particularly important when the organisation's environment is unstable and changing (Steyn 2007). Strategic communication management, and particularly environmental scanning to gauge the needs, attitudes and perceptions of role players, plays an essential role in the unstable and changing environment of disaster risk reduction (DRR), response and recovery management. In DRR management, strategically planned communication and strong organisation-stakeholder relationships are vital, because they can reduce the extent of disaster risks and save lives during disasters.

Numerous role players ${ }^{1}$, such as the Potchefstroom Fire Brigade, Potchefstroom Fire Protection Association

1.The term 'stakeholders' refers to people, or organisations, who are affected by the decisions and actions of an organisation or whose decisions and actions affect the organisation (Grunig \& Repper 1992:125; Steyn \& Puth 2000:5). In this paper, the organisation (Grunig \& Repper 1992:125; Steyn \& Puth 2000:5). In this paper, the
term 'role players' is used to refer to the different emergency services, such as the term 'role players' is used to refer to the different emergency services, such as the
SAPS, Fire Brigade and the FPA who were involved in fighting the veld fires on 23 August 2011 in the Tlokwe Local Municipality. These organisations are also each August 2011 in the Tlokwe Local Municipality. These organisations are also each
other's stakeholders, but the term 'role players' indicates a side-to-side working relationship on that specific day.
(FPA), Potchefstroom Disaster Management Volunteers, farmers, North-West University Fire Brigade, Society for the Prevention of Cruelty to Animals (SPCA), Working on Fire and the South African Police Service (SAPS) Mounted Academy, amongst others, were involved in fighting the veld fires of 23 August 2011. Each of these role players should have planned for the occurrence of veld fires, and they had to have strong relationships with each other to be able to work together in combating such a disaster. In the following section, relationship management as the most important outcome of strategic communication management will be discussed.

\section{Relationship management}

Exchange and communal relationships are the two main types of relationships between an organisation and its stakeholders (Hon \& Grunig 1999). An exchange relationship is one in which members benefit from one another in response to specific benefits received in the past or expected in the future (Hung 2005, 2007; Newsom et al. 2010), and economic exchanges are at its core (Clark \& Mills 1979, 1993). Communal relationships are characterised by commitment and goodwill amongst those in the relationship, and they are concerned about the others' welfare (Clark \& Mills 1979, 1993; Grunig 2000; Newsom et al. 2010; Paine 2003). In a communal relationship the benefactor does not expect the beneficiary to return the favour (Hon \& Grunig 1999; Hung 2007). According to Hung $(2005,2007)$, exchange and communal relationships strive towards a win-win zone and are viewed as best practice. An organisation's motivation for survival in the institutional environment affects the type of relationship it aims to form with its stakeholders. This implies that organisations do not engage in only one type of relationship with all their stakeholders, but interchange these depending on their situation and their goals (Hung 2001, 2007).

The point made above is also applicable to the veld fire disaster of 23 August 2011, where official disaster risk management (DRM) organisations, such as the Potchefstroom Fire Brigade, Disaster Management Centre and FPA have both communal and exchange relationships with stakeholders such as the farmers whose land was burned down. On the one hand, these organisations receive funds from tax payers or membership fees without having to return such funds, which indicates a communal relationship. On the other hand, the organisations also have exchange relationships with stakeholders because stakeholders expect the organisations to deliver certain services to them, for which they (the stakeholders, such as farmers) indirectly pay with taxes and membership fees. All these role players also have communal relationships with each other, which are characterised by trust, commitment and goodwill.

Relationship outcomes indicate the quality of the relationship between the organisation and its stakeholders and an organisation must strive towards strengthening these outcomes (Hon \& Grunig 1999; Huang 2001; Hung 2001; Jahansoozi 2007; Newsom et al. 2010): 
- Trust refers to one party's level of confidence in the other party. Trust has underlying dimensions such as:

- integrity, which is the belief that each party operates in a fair and just manner

- dependability, which refers to the belief that each party will do what it says it will do

- competence, which refers to the belief that each party can do what it says it will do.

- Control mutuality (or mutual control) refers to the extent to which parties agree on who has rightful power to influence or control the other in a given situation or context.

- Commitment entails that all parties involved feel that the relationship is worth spending time and energy on.

- The level of relationship satisfaction refers to the extent to which one party is favourably disposed toward the other because the expectations and experience regarding the relationship are positive. It is therefore necessary for all role players in DRR to build and maintain relationships continually with each other and their stakeholders by applying two-way communication in such a way as to encourage trust and commitment, which, in turn, will enhance willingness to share control. Only then will all parties involved experience a mutually satisfying relationship.

Several relationship-cultivation strategies can be applied to build strong relationships between all role players and their stakeholders concerning a specific disaster risk. Some of the strategies applicable to DRR are (Grunig \& Huang 2000; Hung 2001, 2007; Plowman 1998, 2005):

- Access: access to information is made easy, and all parties are granted access to organisational decision-making processes, which leads to improved mutual control and trust between parties.

- Openness or disclosure: all parties must be willing to provide information to each other (depending on the nature of the relationship), whilst those with greater power have the obligation to prove that it is in the interest of those with less power not to have access to certain information. This will add to improved trust between the parties involved.

- Assurances of legitimacy: this involves efforts by the parties in a relationship to express their commitment to maintain the relationship, which leads to more satisfaction and commitment from both sides.

- Networking: this pertains to organisational efforts to build networks with the same groups as its stakeholders, such as environmentalists, unions, or community groups. Networking is valuable in DRR management because it is a way to engage with all parties in the discipline.

- Sharing of tasks: all parties involved solve problems together, for example, the Fire Brigade and FPA can work together to reduce and fight veld fires.

- Cooperating: all parties involved strive toward bringing together their interests, in order to reach a mutually beneficial relationship.

- Being unconditionally constructive: each party involved does its best for the relationship, even if it has to give up some of its aims and all parties do not respond to its good intentions.
- Keeping promises: organisations keep promises to achieve dependability and competence, which are both dimensions of trust. This is a very important relationship cultivation strategy concerning DRM since stakeholders depend on organisations such as the municipal Disaster Risk Management Centres, the Fire Brigade Services, ambulance services and the FPA to prevent and manage fire hazards. Keeping promises is also very important in the relationship between role players since they rely on each other in very dangerous situations.

The above discussion on strategic communication and relationship management leads to the formulation of the study's research objectives.

\section{Research objectives}

The research objectives for this paper were:

- How did the different role players perceive communication management during the veld fires of 23 August 2011?

- In what way were relationships between role players affected by communication during the veld fires of 23 August 2011?

\section{Research methodology}

The research approach to the study as well as the research methods followed to obtain the data will be discussed in the next section.

\section{Research approach and method}

A qualitative research approach was followed in order to obtain a deeper understanding (Leedy \& Ormrod 2001; Lindlof 1995) of the way in which communication was managed during the veld fires in the Tlokwe Local Municipality on 23 August 2011 and its effect on stakeholder and inter-role player relationships.

Semi-structured interviews (Leedy \& Ormrod 2001; Rubin \& Rubin 1995) containing open-ended questions (Babbie 2001; Du Plooy 2002; Sarantakos 2005) were conducted with:

- three senior managers from the Potchefstroom Fire Brigade

- Potchefstroom and/or Tlokwe Disaster Management Centre's Crisis Control Officer

- Klerksdorp

- Fire Chief

- Fire Protection Officer

- North-West University, Potchefstroom Campus's Fire Chief

- Chairman of the Northwest Umbrella Fire Protection Association;

- Potchefstroom FPA's

- Chairman

- Vice-Chairman

- Communication Manager

- four Area Heads

- 11 farmers affected by the veld fires. 
All of the interviews were recorded digitally to ease correct analysis of data. All of the participants agreed to the recording of the interviews. The main purpose of the interviews was to obtain an understanding of the communication, and its effect on relationships during the veld fires of 23 August 2011. Therefore, the interviews aimed to:

- determine how the different role players perceived communication management during the veld fires of 23 August 2011

- determine in what way, if at all, relationships between role players were affected by communication during the veld fires of 23 August 2011.

An interpretative approach to data analysis was followed to analyse the data. Theory on strategic communication and relationship management were used to guide the analysis of the data obtained during the interviews.

\section{Findings}

The report on the findings of the study will be divided into two sections. The first section will describe the communication protocol that should be followed during veld fires, whereafter the actual communication procedure followed during the veld fires of 23 August 2011 will be reported.

\section{Communication protocol during veld fires}

Most of the farmers in the Tlokwe Local Municipality are members of the Potchefstroom $\mathrm{FPA}^{2}$ and/or Disaster Management Potchefstroom Volunteers ${ }^{3}\left(\mathrm{DMPV}^{4}\right)$. Both 'organisations' are commonly referred toas theFPAby farmers. The FPA coordinates veld fire prevention and management in the rural areas of the Tlokwe Local Municipality. It functions as part of Tlokwe Disaster Management, and supports the Potchefstroom Fire Brigade in fighting veld fires.

Whenever smoke is spotted by a farmer in the Tlokwe Local Municipality, it is reported on the FPA two-way radio system, followed by an immediate investigation by the farmer in question. Whoever hears the report repeats the warning that smoke has been seen and asks other farmers to be prepared in the event of a significant fire. When the investigating farmer reports that they cannot control the veld fire by themself, the nearest farmers should come to their aid. The area head takes control of the management of the fire and calls the FPA chairman who will inform the Fire Brigade. This is done by calling the call centre at the Tlokwe Disaster

2.The FPA operates according to the National Veld and Forest Fire Act 101 of 1998 in order to prevent and fight veld fires.

3.The FPA forms part of the Disaster Management Potchefstroom Volunteers (DMPV), and the DMPV functions as part of the Tlokwe Local Municipality's Disaster Management Centre. The DMPV provides its members with education, information advice and training regarding DRM, which includes fighting veld fires, floods and enhancing safety on farms. The FPA and the DMPV are managed by the same management team.

4.The DMPV plays a supporting role in DRM, as outlined by the Disaster Management Act 57 of 2002 (DMA) (South Africa 2002). The Act makes provision for the formal managerial structures and duties of Disaster Management Centres at national, provincial, and municipal levels. According to the DMA, a local municipality may provincial, and municipal a unit of volunteers that is trained to assist emergency services during
disasters. The Act outlines the management structure, training and duties of disasters. The
volunteers.
Management Centre. The moment the message is relayed to the Fire Brigade, the Fire Brigade start preparing in case assistance is needed. With early warning, the Fire Brigade can determine how they will be responding. The FPA chairman will dispatch the Fire Brigade only if the FPA and farmers cannot control the veld fire. No farmer is allowed to contact the Fire Brigade individually, but must go through the area leaders, who speak to the FPA Chairman, who reports to the Fire Brigade. This procedure ensures that the Fire Brigade is not called by several people concerning the same fire.

It might also happen that a person not affiliated to the FPA reports a veld fire. Calls regarding veld fires are received either by radio or by telephone at the control room situated at the Tlokwe Disaster Management Centre. The call is then sent through to the Fire Brigade who respond accordingly. The first fire-fighter at the scene evaluates the situation, and if they cannot manage the fire, they report to the Fire Brigade's station officer who will then go out to the fire to assess the situation. If the veld fire is unmanageable, more senior officers' assistance is called in. The highest ranking officer on the scene will take command and coordinate the fire-fighters as well as the FPA and farmers.

If the veld fire is out of control, as happened on 23 August 2011, the Fire Chief should inform the Tlokwe Disaster Manager who will manage the situation logistically, with the aid of senior managers of all emergency services involved. The Tlokwe Disaster Manager should alert the Kenneth Kaunda District Disaster Risk Management Centre to be on standby, and they will in turn alert the Provincial and National Disaster Management Centres. According to the severity of the veld fires, spotter aeroplanes can be mobilised by the Disaster Manager to provide the Fire Chief and firefighters with information on the location and severity of the fires. The entire fire-fighting operation can then be planned, utilising information from the spotter aeroplane and ground personnel. The Tlokwe Disaster Manager dispatches Traffic Control, Provincial ambulance services, the SAPS and other necessary emergency services as needed. If the Disaster Manager has called upon all local fire-fighting and emergency resources, such as the North-West University, Potchefstroom Campus's Fire Brigade, the SAPS Mounted Academy, ER-24 (a private ambulance service provider) and the Potchefstroom South African National Defence Force (SANDF) Fire Brigade, the Kenneth Kaunda District Disaster Risk Management Centre should be asked for assistance.

\section{Communication during the veld fires of 23 August 2011}

On the morning of 23 August 2011, smoke was seen on the eastern boundaries of Potchefstroom. The smoke was heading in a north-westerly direction. At that stage it was outside the Potchefstroom boundaries and the wind speed was approximately $20 \mathrm{~km} / \mathrm{h}-25 \mathrm{~km} / \mathrm{h}$. However, it was a 'code red day' (according to the Fire Danger Rating), with a high possibility of veld fires. At about 11:00, farmers in Call 
group $1^{5}$, at the northern side of Potchefstroom, reported on the FPA two-way radio system that they were investigating smoke. They reported that a severe veld fire was heading toward Potchefstroom. All farmers were alerted to be on standby and the FPA chairman called the control room at the Tlokwe Disaster Management Centre to report the veld fires to the Fire Brigade.

From this point on, for no known reasons, no official procedures were followed. A deputy fire-fighter was in control of the fire-fighting. The Fire Chief and Deputy were on their way to a workshop in Hartbeespoort; they saw the fires but did not stop to investigate. According to an interviewee, neither the Fire Chief nor his Deputy was informed about the severity of the veld fires. However, another interviewee refuted the statement strongly. Several role players tried to get hold of the Disaster Manager, who should have performed the role of Incident Commander, but to no avail. It should be noted that, according to several interviewees, the Tlokwe Disaster Manager was called on all his contact numbers. The Tlokwe Disaster Management Centre's Crisis Control Officer represented the Disaster Management Centre, but he had no formal decision-making powers or strategic experience in disaster management. The Kenneth Kaunda Disaster Risk Management Centre was subsequently not informed about the veld fires, and the District Disaster Manager heard about it only days later from an academic from African Centre for Disaster Studies at the North-West University. According to the District Disaster Manager, none of the role players, not even the Ventersdorp Fire Chief, from whose area the veld fires originated, informed him about the disastrous veld fires.

Due to the lack of strategic managers, each role player tried their best to fight the veld fires on their own. A Joint Operations Centre (JOC) was established north of Potchefstroom by the Potchefstroom deputy fire-fighter; another JOC was established at Carletonville by a Working on Fire team and Carletonville's Fire Chief; and a third JOC was located at the house of the FPA's chairman. The FPA chairman managed the farmers as members of the FPA to fight the veld fire, and he was in radio contact with several role players such as the SAPS and the Fire Brigade. Incident commanders at the various JOCs were in contact with each other, and they dispatched the different emergency services from the whole Kenneth Kaunda District.

Difficulties concerning physical communication added to the chaos since all role players used different two-way radios and different radio frequencies in order to communicate. They were therefore unable to communicate with each to coordinate their efforts. In some areas there was also no cell phone reception.

5.The Potchefstroom Local Municipality's rural area is divided into seven divisions. These divisions are referred to as the seven Call Groups, which are divided into 75 wards. If a farmer calls in a veld fire, they identify themselves by a specific call 75 wards. If a farmer calls in a veld fire, they identify themselves by a specific call number, which indicates the call groups and ward they fall under.
members immediately to determine the location of the veld fire.
The Tlokwe Disaster Manager could not be reached for official permission, and therefore no spotter aeroplanes were dispatched to inform the role players about the location and direction of the veld fires. The FPA used a Geographic Information System (GIS) satellite system from NASA to determine where the fires were. However, the wind was very strong and it changed direction constantly. The GIS system could not provide immediate information on the position and severity of the veld fires. Nonetheless, the GIS system's information was better than no information at all.

Another problem experienced was a lack of fuel for some of the emergency vehicles because of the municipalities' nonpayment of fuel bills. In some cases, members of the FPA filled government vehicles' tanks in order for them to fight the veld fires. Both the Tlokwe Disaster Management Centre's Crisis Control Officer's official and personal cell phones' airtime quickly ran out, and as a result he could not further manage the situation. One of the FPA members loaded airtime onto his cell phone, to enabling him to continue his work.

In the following discussion, the communication management during the veld fire disaster of 23 August 2011 will be positioned against the normative theoretical framework of communication and relationship management in order to highlight the pragmatic reality of communication management during veld fire disasters.

\section{Discussion}

The discussion will be divided into two sections. In the first section, the role players' perception of communication management during the veld fires of 23 August 2011 will be discussed. The quality of communication management has a direct effect on the quality of relationships between role players, and therefore the role players' perception of the effect that the communication during the veld fires of 23 August 2011 had on relationships will be discussed.

\section{Role players' perception of communication during the veld fires of 23 August 2011}

All interviewees, except the farmers, agreed that communication during and management of the veld fires of 23 August 2011 was chaotic and insufficient. The absence of the Tlokwe Disaster Manager and Fire Chief hindered both the achieving of a strategic approach to managing the disaster, as well as the obtaining of the necessary resources from district and national level. If the District Disaster Manager was notified, more resources such as spotter planes and finances for fuel could have been made available. Furthermore, the District Disaster Manager would have been able to provide the necessary resources immediately. It was concluded that the extent of the damage could have been less if the disaster was managed more strategically.

Many of the interviewees pointed out that the control room at the Tlokwe Disaster Management Call Centre was a weak 
link in the communication chain during the veld fires. Two of the interviewees noted that call centre personnel do not have any emergency training and therefore do not understand the circumstances when an emergency call comes through. Some of the call centre personnel do not realise that they have to relay the calls immediately to the relevant emergency services. Three interviewees added that calls to the call centre were not answered, or that the phone was picked up and immediately put down again. Another constraint, not specific only to the veld fires of 23 August 2011, is the language barrier between the different language groups in the Tlokwe Local Municipality. This leads to misinformation as well as emergency services not reaching people in time. From a communication management perspective, this implies that the persons responsible for the technical implementation of communication were incompetent. In such an instance the communication management process would be unsuccessful, even if it were planned strategically.

On the question as to why the role players failed to let the District Disaster Manager know about the veld fires, many pointed out that they 'thought the call centre would let him know' or that 'the Fire Brigade has to let him know' and 'it is not my place to call him [the District Disaster Manager]'. Firstly, it is clear that many role players do not know the communication procedure during veld fires and secondly, the absence of (especially) the Tlokwe Disaster Manager had a profound impact on communication between role players as well as to the district level.

All of the interviewed farmers praised the FPA and their communication systems that kept them updated with information. No-one criticised the emergency services. According to the farmers, everybody did their best to save lives, cattle and grazing. It is important to note that the farmers did not communicate directly with emergency services, but made use of the FPA's communication structures. According to several interviewees that included official role players, the FPA played a huge role in extinguishing the veld fires. One source estimated that the farmers extinguished about $40 \%$ of the veld fires. The afore-mentioned source praised the FPA's communication system as being very efficient. It became clear that the FPA's technical communication system with its members is very effective. However, strained relationships hampered communication, especially between and with official role players. As mentioned before, the role players' perception of the way in which communication was managed during the veld fires of 23 August 2011 has an influence on the quality of the relationship between the different role players. The perceived effect of the communication during the veld fires of 23 August 2011 on role player relationships will be scrutinised in the following section.

\section{Role players' perception of the effect on relationships of communication during the veld fires of 23 August 2011}

The veld fires of 23 August 2011 had a profound impact on the hearts and minds of all involved, but, most significantly, the lack of strong leadership and coordinated communication harmed relationships between most of the role players. It was especially trust, which should be an outcome of strong relationships, which was damaged.

Seemingly, the perception remained that the absence of the Tlokwe Disaster Manager created most of the chaos and lack of communication. The reasons as to why the Tlokwe Disaster Manager was absent on 23 August 2011 is still not known, and consequently his commitment to his job was questioned by all role players. A serious after-effect of the Tlokwe Disaster Manager's absence is that many role players are of the opinion that since they cannot trust the Tlokwe Disaster Manager, they also cannot trust the Tlokwe Disaster Management Centre itself to be available and competent during disasters. From a theoretical viewpoint this indicates that particularly the Tlokwe Disaster Manager, but also the personnel from his office, will have to work hard to repair the relationship with all role players. Sharing tasks, cooperating with other role players and networking, perhaps informally, might assist the Tlokwe Disaster Manager in repairing relationships. However, the most important relationship cultivation strategy would be to keep his promise to be available and to provide leadership during disasters. Only then would role players truly trust his commitment to his job.

The simultaneous absence of the Potchefstroom Fire Chief also harmed trust in the Fire Brigade, and two of the interviewees mentioned that he does not have a hands-on management approach to veld fire-fighting. This perception indicates that some role players believe that the Fire Chief is not committed to his job and can therefore not be trusted to do his job effectively. This implies that the Potchefstroom Fire Chief will also have to repair trust, not only in himself as a leader, but also in the Fire Brigade as an entity.

Due to the supposed close cooperation between the Tlokwe and District Disaster Managers, both their reputations were damaged because all role players assumed that the Tlokwe Disaster Manager, or his office, would have notified the District Disaster Manager about the veld fires. It was assumed that the District Disaster Manager chose not to be involved, and this assumption also damaged trust in both him and his office. Fortunately, this negative assumption was cleared by the District Disaster Manager himself, especially when he provided assistance (grazing) to farmers after the veld fires.

It has to be mentioned though that all the interviewed emergency services held the Tlokwe Disaster Management Centre's Crisis Control Officer in high regard because he tried his best to assist in fighting the veld fires. His willingness and dedication to his work helped to repair some of the already mentioned negativity toward the Tlokwe Disaster Manager and the Tlokwe Disaster Management Centre. Although some interviewees were of the opinion that the Crisis Control Officer was unable to manage the veld fire disaster 
strategically, their relationship with him was not hampered because he illustrated integrity and dependability during the disaster. Both integrity and dependability are dimensions of trust as an outcome of strong relationships. Furthermore, the Crisis Control Officer's commitment and mutual control (he worked with the FPA and the Chairman of the Northwest Umbrella Fire Protection Association) of the situation led to a satisfying relationship with all role players. Theoretically, this implies that even though one of the dimensions of trust (competence) was perceived to be absent, the communication and relationship between the Crisis Control Officer and other role players was still satisfactory.

The relationship between most of the interviewed role players from the emergency services and the control room personnel at the Tlokwe Disaster Management Centre was weakened even further. The interviewees perceived the control room personnel as being incapable and uncommitted, which indicates that there is no trust in these vital emergency services personnel. Training of control room personnel is of the utmost importance if the Tlokwe Disaster Management Centre wants to build and maintain relationships with all role players.

According to some of the interviewed FPA representatives, the FPA chairman provided the Tlokwe Disaster Management Centre and the Fire Brigade (by means of two-way radios and cell phone) with information regarding the veld fires, but has not received any direct $^{6}$ information in return. Theoretically, this implies that the FPA chairman applied the relationship cultivation strategies of providing access to and disclosure of information, but according to him he experienced a 'onesided love affair' with the Tlokwe Disaster Management Centre and the Fire Brigade. This lack of cooperation led to the FPA assuming that the Tlokwe Disaster Management Centre and the Fire Brigade did not want to share control in the situation; that the mentioned authorities did not trust the FPA to do their job; and that the FPA might claim responsibility for successfully fighting the fires. Two interviewees from emergency services agreed that some of the above assumptions are correct, since it might appear 'that the FPA is doing the Fire Brigade's work'. However, the FPA chairman emphasised that fighting veld fires is a team effort, and no one emergency service can take all the credit in such a situation.

When the District Disaster Manager heard about the veld fires, his first reaction was that the Tlokwe Local Municipality had to manage the situation themselves. However, he soon realised that everybody was 'totally overwhelmed' by the severity of the veld fire disaster. Subsequently, they only did what was known to them (their operational fire-fighting and related tasks) and did not stop to 'see the bigger picture'.

6.The Tlokwe Disaster Management Centre conveyed information to the Tlokwe Crisis Control Officer, who in turn communicated with the FPA and the Chairman of the
Northwest Umbrella Fire Protection Association. The Tlokwe Disaster Management Centre allegedly refused to communicate directly with the FPA Chairman.
He continued by noting that they couldn't 'see the forest through the trees', which is a task of the senior emergency services managers. It can be assumed though that the Tlokwe Disaster Management Centre as an entity also damaged their relationship with District and National Disaster Management, and that special effort would be needed to persuade District and National Disaster Management of their dependability, competence, commitment and trustworthiness in the future.

With reference to the above view of the District Disaster Manager about the overwhelming nature of the veld fires, several of the interviewed farmers emphasised that 'even if the fire fighting and communication was managed 100\% correctly, nothing could have stopped the damage'. Many farmers could not receive any assistance since there were too many veld fires to attend to. The farmers' perception of the communication on 23 August 2011 is that they did not experience such negative communication from the emergency services as to damage relationships. Their trust in each other (this includes farmers from different racial groups), as well as in the FPA were reinforced because they received continuous information from the FPA chairman (as incident commander at the JOC), and the FPA managed the farmers well during the fighting of the veld fires. It is important to note that the farmers themselves did not communicate directly with emergency services. All communication was coordinated by the FPA chairman. The farmers believed that communication between the FPA and all other emergency services went well, and therefore none of the farmers were of the opinion that their relationship with any emergency service was hampered.

\section{Conclusion}

It is clear from the above discussion that the veld fires of 23 August 2011 were a disaster with not only huge financial losses, but also an immense effect on all the people involved. The exceptionally strong winds caused the raging veld fires to change direction constantly, leading to grazing land and cattle losses. In these circumstances all farmers and emergency services did their best to fight the fire. However, many relationships between role players were damaged.

That being said, two interviewees noted that as an aftermath of the veld fire disaster, communication between role players actually improved, because their dependability on each other during a disaster became clear. Communication between role players is, according to one interviewee, 'more meaningful, and hopefully people will trust each other more'. Many of the role players also attend the advisory forums more regularly, and are getting to know each other better. This then helps the role players to understand each other's issues, limitations and strengths that in turn add to trusting relationships.

There are some recommendations that can be made to enhance communication and relationship management during veld fire disasters, and they will be discussed in the following section. 


\section{Recommendations}

From a practical viewpoint, it seems necessary to train relevant emergency services personnel in strategic incident communication management in order to prevent a recurrence of the communication malfunction of 23 August 2011. In other words, if the senior commanding officers are absent, lower ranking officers should know how and when to communicate, and with whom, to manage a disaster effectively with all possible available resources.

It might help the Tlokwe Disaster Management Centre to instil in call centre personnel the importance of their work, because the assumed lack of commitment and competence not only harms relationships with other emergency services, but also with the general public. In this instance, both communal and exchange relationships with the general public, as well as with emergency services, were damaged. Exposure to real situations might add to the call centre personnel's understanding of the urgency of each call, and how to relay the calls to the relevant emergency service. Appointing call centre personnel with excellent language proficiency as well as training them on professional telephone etiquette will also improve the (presently negative) image of the call centre personnel.

It is also recommended that call centre personnel be alerted to the significance of the green/amber/red code status during the dry season to better prepare them to put the disaster management plan into effect when calls come through on a code red status day. This implies that their role in the disaster management plan should be communicated thoroughly to all call centre personnel. Furthermore, all call centre personnel should have the emergency contact details of all senior disaster management personnel.

Participating in simulated emergency situations is invaluable toemergency services, also from a communication perspective. Many emergency services focus only on tactical training, but training on strategic communication management, and focusing on maintaining strong relationships between role players, are lacking. Communication departments from tertiary institutions can add valuable input in this instance. It is also important to provide thorough training to emergency services personnel with regard to the monitoring and management of software systems, such as the Advanced Fire Information Service (AFIS). Training on communicating the gathered information to relevant role players during a disaster, is also crucial.

This paper argues that by planning disaster communication management from a relationship management approach, cooperation and coherence between all role players might be strengthened during disasters. The relationship management approach posits that in order to build trust, all actions and communication must be characterised by integrity, dependability and competence. There must be agreement about mutual control in a disaster, and all role players must be committed to doing their utmost to keep the relationship satisfactory (which implies doing one's work well). A relationship management approach to disaster communication might step away from 'tick lists', but the outcome might prove much more satisfactory.

Further research on strategic communication and relationship management in disaster risk reduction, response and recovery is necessary not only to build normative theory, but to add to pragmatic knowledge.

\section{Acknowledgements Competing interests}

The author declares that she has no financial or personal relationship(s) which may have inappropriately influenced her in writing this article.

\section{References}

Anon, 2008, 'Farmers count the cost as devastating fires rage', Star, 4 September, p. 5. Anon, 2010, 'Brande saai oral verwoesting', Landbouweekblad, 22 October, p. 61.

Babbie, E., 2001, The practice of social research, 9th edn., Wadsworth, Belmont, CA.

Cilliers, S., 2011, 'Noordwes-brande: boere moet volle skade help bepaal', Beeld, 31 Augustus, p. 8.

Clark M.S. \& Mills, J., 1979, 'Interpersonal attraction in exchange and communal relationships', Journal of Personality and Social Psychology 37(1), 12-24. http:// dx.doi.org/10.1037/0022-3514.37.1.12

Clark M.S. \& Mills, J., 1993, 'The difference between communal and exchange relationships: what it is and is not', Personality \& Social Psychology Bulletin 19(6), 684-691. http://dx.doi.org/10.1177/0146167293196003

Coleman, A., 2011, 'Devastating veld fires in North West and Free State', Farmers Weekly, 9 September, p. 30.

Cutlip, S.M., Center, A.H. \& Broom, G.M., 2000, Effective public relations, 8th edn., Prentice Hall, Upper Saddle River, N.J.

Davies, R., 2011, 'Vlammehel! Geen keer aan golwende vlamme nie', SENWES Scenario, October, pp. 4-8.

Du Plooy, G.M., 2002, Communication research: techniques, methods and applications, Juta, Lansdowne.

Grunig, J.E., 2000, Qualitative methods for assessing relationships between organizations and publics, Institute for Public Relations, Gainesville, FL.

Grunig, J.E. \& Grunig. L.A., 2000, 'Public relations in strategic management and strategic management of public relations: theory and evidence from the IABC Excellence project', Journalism Studies 1(2), 303-321. http://dx.doi. org/10.1080/14616700050028271

Grunig, J.E. \& Huang, Y.H., 2000, 'From organizational effectiveness to relationship indicators: antecedents of relationships, public relations strategies, and relationship outcomes', in J.A. Ledingham \& S.D. Bruning (eds.), Public relations as relationship management, pp. 23-53, Lawrence Erlbaum, Mahwah, N.J.

Grunig, J.E. \& Repper, F.C., 1992, 'Strategic management, publics and issues', in J.E. Grunig, D.M. Dozier, W.P. Ehling, L.A. Grunig, F.C. Repper \& J. White (eds.), Excellence in public relations and communication management, pp. 117-158, Lawrence Erlbaum, Hillsdale, N.J.

Grunig, L.A., Grunig, J.E. \& Dozier, D.M., 2002, Excellent public relations and effective organizations: a study of communication management in three countries, Lawrence Erlbaum, Mahwah, N.J.

Hon, L. \& Grunig, J.E., 1999, 'Guidelines for measuring relationships in public relations' Gainesville, FL: Institute for Public Relations, viewed 12 July 2012, from http:// www.instituteforpr.org/research_single/guidelines_measuring_relationships/

Huang, Y-H., 2001, 'OPRA: a cross-cultural, multi-item scale for measuring organization-public relationships', Journal of public relations research 13(1), 6190. http://dx.doi.org/10.1207/S1532754XJPRR1301_4

Hung, C.F., 2001, 'Toward a normative theory of relationship management', viewed 12 July 2012, from http://www.instituteforpr.org/research_single/normative_ theory/

Hung, C.F., 2005, 'Exploring types of organization-public relationships and their implications for relationship management in public relations', Journal of Public Relations Research 17(4), 393-425. http://dx.doi.org/10.1207/ s1532754xjprr1704_4

Hung, C.F., 2007, 'Toward the theory of relationship management in public relations: how to cultivate quality relationships?', in E.L. Toth (ed.), The future of excellence in public relations and communication management: challenges for the next generation, pp. 443-476, Lawrence Erlbaum, Mahwah, N.J. 
Jahansoozi, J., 2007, 'Organization-public relationships: An exploration of the Sundre Petroleum Operators Group', Public Relations Review 33(4), 398-406. http:// dx.doi.org/10.1016/j.pubrev.2007.08.006

Leedy, P.D. \& Ormrod, J.E., 2001, Practical research: planning and design, 7th edn., Merrill Prentice-Hall, Upper Saddle River, N.J.

Ledingham, J.A. \& Bruning, S.D., 1998, 'Relationship management in public relations: dimensions of an organization-public relationship', Public Relations Review 24(1) Spring, 55-65. http://dx.doi.org/10.1016/S0363-8111(98)80020-9

Lindlof, T.R., 1995, Qualitative communication research methods, Sage, Thousand Oaks, CA.

Meyer, L., 2002, 'Brande in Noordwes knak boere', Rapport, 21 July, p. 4.

Newsom, D., Turk, J.V. \& Kruckeberg, D., 2010, This is PR: the realities of public relations, 10th edn., Wadsworth Cengage Learning, Boston.

Paine, K., 2003, 'Guidelines for measuring trust in organizations', paper presented to the Institute for Public Relations Commission on PR Measurement and Evaluation, Gainesville, Florida, unpublished.

Plowman, K.D., 1998, 'Power in conflict for public relations', Journal of Public Relation Research 10(4), 237-261. http://dx.doi.org/10.1207/s1532754xjprr1004_02

Plowman, K.D., 2005, 'Conflict, strategic management, and public relations', Public Relations Review 31(1), 131-138. http://dx.doi.org/10.1016/j.pubrev.2004.10.003
Rubin, H.J. \& Rubin, I.S., 1995, Qualitative interviewing: the art of hearing data, Sage, Thousand Oaks, CA.

Sarantakos, S., 2005, Social research, 3rd edn., Palgrave Macmillan, Houndmills.

South Africa, 1998, National Veld and Forest Fire Act 101 of 1998, Government Printer, Pretoria.

South Africa, 2002, Disaster Management Act 57 of 2002, Government Printer Pretoria.

Steyn, B., 2007, 'Contribution of public relations to organizational strategy formulation', in E.L. Toth (ed.), The future of excellence in public relations and communication management: challenges for the next generation, pp. 137-172, Lawrence Erlbaum, Mahwah, N.J.

Steyn, B. \& Puth, G., 2000, Corporate communication strategy, Heinemann, Sandton.

Tau, S., 2008, 'Severe weather damage report soon. Havoc: Departments expected to announce extent of losses', Citizen, 3 September, p. 3.

Van Der Walt, N., 2012, 'Brande vreet reeds 360000 ha landbougrond', Beeld, 10 September, p. 2.

Van Niekerk, D. \& Coetzee, C., 2011, Rapid impact assessment: veld fires in the Tlokwe local Municipality, 23 August 2011, ACDS, North-West University, Potchefstroom. 